\title{
Reading the Margins of Business Censuses
}

\author{
The Garment Industry and Home-based Industrial Work in Sweden and \\ Finland, 1930 s to 1960 s
}

\section{Laura Ekholm}

This chapter analyses how home-based work and home workers were treated in specific nationwide business censuses in Sweden and Finland, especially in regard to the garment industry. This chapter attempts to study how the business censuses of 1931 and 1951 for Sweden, and of 1953 and 1964 for Finland, collected, defined, categorized, and reported data on home-based work and home workers. ${ }^{1}$

A basic premise of the chapter is that statistical censuses, just as with any other type of information, represent produced knowledge: governmental statistical agencies make a number of decisions and compromises when planning and implementing surveys and arranging the collected data. Statistical tables, therefore, are always a social construction and a compromise between many contradictory demands. What types of questions are asked and how the collected information is defined and categorized often reflect the structures, values, and needs of contemporary society. Conducting nationwide censuses is a laborious and expensive process. Hence all such collected information needs to bear social relevance, and herein lies the twist: the statistical tables always reflect social values.

The attempts and decisions regarding how to account for small-scale, arts and crafts industries illustrate a basic challenge in evaluating statistical information. To begin with, no published statistical table can include all the collected information. In addition, statistics are constantly changing. On the one hand, statistics need to describe trajectories over time; on the other, they should grasp new trends. New categories emerge while older ones become marginal. In this respect, the classification categories that disappear over time from published tables and the information that gets omitted can be as interesting as the published data.

11931 års företagsräkning (Stockholm, 1935); 1951 års företagsräkning (Stockholm 1955); 1953 års företagsräkning (Helsinki 196o); Företagsräkningen 1964 (Helsinki 1970).

(C) LAURA EKHOLM, 2022 | DOI:10.1163/9789004499614_004

This is an open access chapter distributed under the terms of the CC BY-NC-ND 4.o license. 
The availability of ready-made clothing symbolizes the rise of a modern consumer society where almost everyone can afford new garments and adopt novel fashions. Between the 1930s and the 1960s in Sweden and Finland, there was a shift from traditional, artisanal manufacturing of clothes to a standardsized, ready-to-wear garment industry. Many major transformations occurred and intensified over these decades, ranging from how people lived, worked, and dressed, how often and where they bought new clothes, to how garment production was organized.

The garment industry played a significant role in the making of modern industrial Nordic societies. In 1951, in Sweden, textile and apparel companies comprised more than 20 per cent of all industrial firms, and the sector employed 15 per cent of the industrial workforce. In terms of providing employment, the garment industry was second only to the metal and machinery industries. ${ }^{2}$ In Finland, in the early 1960s, the textile and garment industry employed approximately 15 per cent of the industrial workforce. ${ }^{3}$ Above all, in both countries it was by far the most important industrial employer of women.

Whereas one of the most common themes associated with the history of European clothing concerns the "evil of sweating", ${ }^{4}$ Swedish and Finnish scholarly literature has emphasized the rapid technological developments that took place in garment manufacturing in the interwar period. ${ }^{5}$ In contemporary discourse, the objective of rational, efficient manufacturing coincided with ideas about public and individual health; the press promoted factory production as a guarantee of good hygiene. ${ }^{6}$ At the same time, for Swedish ready-to-wear companies home workers were a crucial part of the story. In Sweden of the 1950s, the norm for married women was to stay at home. ${ }^{7}$ This raises the question

21951 årsföretagsräkning [hereafter 1951 Census of Production, Distribution, and Services] (Stockholm: Kommerskollegium, 1955), p. 33 .

3 Företagsräkningen 1964 [hereafter 1964 General Economic Census I] (Helsinki: Tilastokeskus 1971), pp. 42-43.

4 Andrew Godley, "The development of the clothing industry: Technology and fashion", Textile History, 28 (1997), pp. 3-10, 6-7.

5 For example, Erik Dahmén, Svensk industriell företagarverksamhet: Kausalanalys av den industriella utvecklingen 1919-1939, I (Stockholm, 1950), pp. 152-53; Piippa Lappalainen and Mirja Almay, Kansakunnan Vaatettajat (Helsinki, 1996).

6 Ulrika Kyaga, "Swedish fashion 1930-196o: Rethinking the Swedish textile and clothing industry", Ph.D. dissertation (Stockholm University, 2017), pp. 187-88.

7 Carina Gråbacke, Kläder, shopping och flärd: Modebranschen i Stockholm 1945-2010 (Stockholm, 2015), pp. 102-03. 
of the significance of home-based work for the growing garment industry in Sweden.

Finland, with a population roughly half that of Sweden, not only had a smaller economy, but was also a predominantly rural society until the late 196os. For the Finnish garment industry, anecdotal evidence draws from the years of the Second World War and the postwar material scarcity. The theme of home work is more or less absent in twentieth-century Finnish literature. ${ }^{8}$ The rationalization for such an outcome is a perplexing mixture of underindustrialization and rapid social and economic transformation, raising many new questions about the role of home-based work in postwar Finland.

This chapter, then, examines the following questions. How were home workers and home-based work accounted for in the original surveys in Sweden and in neighbouring Finland? How, if at all, was this information taken into account in the published census tables? To what extent were the tables able to cover different forms of work in the apparel industry of Sweden? Was Finland too underdeveloped or too modern for home industry? If the category of home workers disappears, does it tell us about the marginalization of home-based work, or does it, rather, reflect contemporary conceptions of predictable and relevant outcomes in the future?

Business Censuses as Sources

Supplementing the annual industrial and manufacturing statistics were the business censuses, conducted at intervals of approximately ten years, which aimed to collect information on all entrepreneurial activities. Due to the very nature of the garment industry, questions concerning home workers and home-based work are not necessarily easy to answer. Industries at the intersection between traditional arts and crafts production, industrial manufacturing, and trade contain multiple, overlapping meanings. Reconstructing developments in the apparel industry is challenging because it essentially functioned in small and micro-sized units. To begin with, small firms were often short-lived since they existed with the intent of providing a livelihood for the owners without any ambition for expansion. They left behind less data than larger corporations. Further, industries where contractual work was commonplace presented a challenge for statistical agencies. Were self-employed

8 Minna Salmi, "Finland Is Another World", in Eileen Boris and Elisabeth Prügl (eds), Homeworkers in Global Perspective: Invisible No More (New York, 1996), pp. 143-67. 
business owners in effect subcontractors for larger firms? What was the threshold beyond which very small, craft-based manufacturers were omitted from the list of part-time workers? Many seamstresses, for instance, distinguished as independent proprietors, worked in positions that were indistinguishable from that of home workers.

The International Convention relating to economic statistics of 1928 obliged countries to collect company-level information on economic activities. The Convention stated that all countries should publish statistical information on such economic indices as professions, businesses, and company-level data. ${ }^{9}$

One of the main aims of the business censuses was to collect data on all enterprises, from large corporations to small proprietary firms including craftbased manufacturers, at a time when there was no up-to-date register of entrepreneurial activities. Whereas individuals constituted the unit of focus in population censuses, business censuses focused on firms of all kinds, from fishing and gardening firms to industrial manufacturing and small-scale arts and crafts firms, to finance, retail, transportation, and service providers. Agriculture was excluded because other statistical entries covered agriculture and forestry, and so also was the case for services pertaining to health, education, and religious institutions.

The business censuses supplemented the population censuses and, more important, the annual industrial and manufacturing statistics. Both Sweden and Finland have collected yearly industrial statistics since the nineteenth century. Collecting information from small manufacturers, especially in the countryside, was both expensive and laborious. Due to rapid industrialization, what had been a normal-sized industrial unit in the 1880s was considered a small company by the 1910s. Beginning in 1913, Swedish industrial statistics included only establishments with at least ten employees, or annual production volume of SEK 10,000 or turnover of SEK 3,000. ${ }^{10}$

In practical terms, the business censuses relied on the same methods as annual industrial accounts, but all registered firms, including the smallest ones, had to fill in the business census forms. The business censuses have proven to be better than industrial statistics for identifying home workers. For example, in 1951, the industrial statistics for Sweden identified only 21,101 home workers in the industrial and manufacturing sectors, while the business censuses reported 32,589 home workers. ${ }^{11}$

9 United Nations Treaty Collection, Chapter XıII: Economic Statistics, available at www.treaties.un.org, last accessed 8 December 2020.

10 Dahmén, Svensk industriell företagarverksamhet, II, p. 7.

111951 Census of Production, Distribution, and Services, pp. 42-43, 18o-81. 
Each company was sent a form with instructions on how to fill in the required information - there were two kinds of forms, one for firms with one to five employees, and the other for larger firms. Generally, the larger companies had more resources (and perhaps interest?) to complete the task. The small companies, on the other hand, were more likely to give non-descriptive and contradictory responses, or to ignore the questions altogether. Nevertheless the census returns, the forms that each company had to complete, offered glimpses of how small-scale businesses functioned, while also reflecting the boundary-lines between home-based workers managing their own accounts and industrial subcontracting. Some companies provided additional information through detailed source material, even if fragmentary in nature.

In order to understand the organizational reality behind the published tables, a sample of census returns is assessed here. I include a sample of business census forms from the ready-to-wear companies in the cities of Gothenburg and Borås in western Sweden from 1931 and 1951, and in Helsinki from 1953 and 1964. The west of Sweden formed a clear cluster of the textile and ready-to-wear industry. ${ }^{12}$ Of the Finnish ready-to-wear producers, 70 per cent operated in Helsinki in the early 196 os. $^{13}$

Needless to say, not all home workers were in the garment industry. It may nevertheless be argued that no other sector was as prone towards home-based work as the garment industry. For example, in 1931, Swedish industry and manufacturing consisted of 90,449 firms employing 713,274 people (excluding the owners) and, in addition, 14,123 home workers. In the same year, more than 8 o per cent of home workers reported in the business census of Sweden were employed in the textile and garment industry. ${ }^{14}$ In the same vein, not all home workers were women. Nonetheless the numbers show how questions about home-based work and female employment are intertwined: women accounted for 82 per cent of all home workers in $1951 .^{15}$

The census returns have been organized into published tables. It is difficult to compare the tables over time, let alone how Sweden compares to neighbouring Finland. For instance, in the 1930s, knitwear could refer to small-scale production of knitted garments, which were typically home-made, as well as

12 Carina Gråbacke and Jan Jörnmark, Den textila modeindustrin i Göteborgsregionen: En Kartläggning (Göteborg, 2008); Kent Olsson, En västsvensk industrihistoria: tiden fram till 1950 (Göteborg, 2012), pp. 51-88.

13 Central Archive for Finnish Business Records, Mikkeli, Central Federation of the Finnish Clothing Industry (Vateva), membership lists 1945-1976, B1:1, B2:1.

141931 års företagsräkning, pp. 42-43.

151951 Census of Production, Distribution, and Services, p. 59. 
to light garments made of synthetic fibres with the production process located in textile mills. By the 196os, knitwear increasingly referred to the latter. Consequently, the product categories and units changed over time. Practical considerations of whether, or to what extent, to report craft-based activities are far from consistent in the records. Comparing tables from one business census to another beyond just aggregated data requires a process of rearranging. For example, whereas in Sweden, the production of men's, women's, and children's ready-to-wear garments was reported separately in $193^{1}$ (115-117), the ready-to-wear industry had been combined into a single category by 1951 (164). The Finnish censuses operated more on an aggregated level-there were no separate categories for artisans, making it difficult to assess what kind of firms operated under the label of the garment industry.

Even more problematic is the fact that the different publications applied various means for reporting the owners, unpaid family members, managerial positions, and different subcategories of employees engaged in production. In 1931, the Swedish census grouped owners and managers into a separate category, whereas in 1951 it listed self-employed business proprietors and any assisting family members first, providing a detailed list of qualifications for different types of employees including those in managerial positions. In the tables given in this chapter, the data have been rearranged to enable comparisons over time. A home worker, as defined in the Swedish and Finnish business censuses, was a contracted outworker, someone working at his or her own premises but under contract to an employer. The one category that remained constant was that of home workers since they were always listed separately.

\section{Reported but Not Published}

All four census forms in the two countries contained a line about the (potential) number of employed home workers in the questionnaire. In the 1931 census, home workers were mentioned as a separate category in all the published tables. Rural women who earned incomes by producing handicrafts, washing and repairing clothes, and other small activities were omitted from the statistics. The same applied for those who held short-term, temporary jobs in a company-for example, seasonal workers at a restaurant or theatre. ${ }^{16}$

161931 års företagsräkning, pp. 27-28. 
Twenty years later, the census of $195^{1}$ only mentioned home workers briefly: "in addition, special information on so-called home workers is included". ${ }^{17}$ It depicted the category of home workers in one table: the number of persons engaged on 7 September 1951, classified according to occupation, etc. 18

To obtain information on the small-scale arts and crafts industry, the statistical agencies in Finland collected data on handicraft-based small businesses every ten years. Collecting and interpreting the data was complicated, and Finnish authorities noted in 1934 that the results were not comparable to proper business censuses such as the 1931 business census of Sweden. ${ }^{19}$

The Finnish business census of 1953 basically contained the same information on home industry as the Swedish census. It defined home industry in parentheses, as consisting of "workers who work at home for a company". Two published tables provided information on home workers: "personnel of establishments" and "average personnel and wages and salaries of establishments". ${ }^{20}$ Finally, in the 1964 Finnish business census, the only reference to home-based work noted that "Home industrial workers, working for the factories from their homes, are not included in the total number of workers". Only one published table provided information on "the personnel and the wages and salaries of establishments". ${ }^{21}$ The 1964 census explained this by noting that "the only sector in which home workers appear are some specific fields of the apparel industry [...]. This above-mentioned group is just a small part of the textile industry". In fact, some 9,00o companies were removed from the 1964 census at the time, since the workers appeared to be working for someone else most of the time, or the company for one reason or another appeared twice in the register. ${ }^{22}$

In theory, the definition of a home worker was precise. In practice, atelier owners, bespoke tailors, and other artisanal manufacturers typically ran very small businesses. Especially in the countryside, they often had home-based operations. At an empirical level, the difference between a self-employed business owner working in his or her own residence and a home-based outworker working for a single employer is not easy to distinguish.

\footnotetext{
171951 Census of Production, Distribution, and Services, p. 26.

18 Ibid., p. 103, 180-213.

19 Finlands Officiella Statistik, XVıı B Hantverkstatistik år 1934 (Helsinki, 1936), p. 3.

201953 General Economic Census, I (Helsinki, 1960), p. 16.

211964 General Economic Census, pp. 52-57.

22 Ibid., pp. 33, 37.
} 
Both contemporary scholars and economic historians in Sweden have pointed out that historical censuses underestimate the role of women in the labour market and as business proprietors. ${ }^{23}$ The censuses only took into account full-time work by drawing a clear distinction between an employer and an employee, whereas women were engaged in part-time work and homebased work more often than men. ${ }^{24}$ Hence, the census data reported married women as being housewives. ${ }^{25}$ This invisibility of the economic impact of women has been one of the main themes of feminist activists campaigning for women's rights. ${ }^{26}$ One of the main reasons for this oversight was that women were more inclined to do home-based work. ${ }^{27}$

A study of the Swedish textile sector in the 1930s revealed a total of 1,100 companies with 90,00o employees and an additional 15,00o home workers. ${ }^{28}$ Measured in this way, home workers accounted for approximately 14 per cent of the workforce in the textile and garment manufacturing industry. The same study also noted that trying to make a distinction between home-based work and home industries is problematic as the garment manufacturing industry is fluctuating and seasonal by nature, and so the boundary between the two categories is quite fluid. The established larger firms relied on the help of independent bespoke tailors and seamstresses whenever the demand was higher than their normal production capacity. ${ }^{29}$ These independent workers might, in turn, contract other self-employed women to help them meet deadlines. In other words, the industry relied to a great extent on subcontracting and home workers, but this reality is barely visible in any of the statistical censuses.

Describing a completely different geographic, historic, and temporal context, Elisabeth Prügl has analysed the situation of a Mexican seamstress working for a contractor in the suburbs of Mexico City in the 199os. In her example, the seamstress identified herself as an entrepreneur. Sometimes she subcontracted her orders to other women to meet deadlines during the high season. At the same time she could not afford to legalize her operations, because that

23 Lena Andersson-Skog, "In the shadow of the Swedish welfare state: Women and the service sector", Business History Review, 81 (2007), pp. 451-70, p. 46o; Margo Anderson, "The history of women and the history of statistics", Journal of Women's History, 4 (1992), pp. $14-36$.

24 Nilsson, "Taking work home".

25 C.-E. Quensel, “Antalet förvärvsarbetande gifta kvinnor i Sverige: Några kommentarer till data från folkräkningen 1945", Ekonomisk Tidskrift, 53 (1951), pp. 244-57.

26 Anderson, "The history of women and the history of statistics".

27 Nilsson, "Taking work home".

28 Kristensson, Studier i Svenska Textila Industriers Struktur, p. 115.

29 Ibid., pp. 152-53. 
would have required her to pay taxes..$^{30}$ Despite obvious non-response biases, it is still easy to account for the number of home workers. In contrast, it is very difficult to assess the role of independent self-employed workers. Hence, it is also important to look at the introductory sections of the published censuses; do they discuss such classification problems and how to solve these problems?

The 1931 census for Sweden contains a lengthy discussion on the difficulties of defining home workers. In terms of occupational categories, the census made an interesting distinction between "industry and handicrafts" and "industry and handicrafts combined with other livelihoods". ${ }^{31}$ This kind of combined category, of which a typical example would be dressmaking and retailing, captured the hidden dynamics underpinning normal classifications wherein officials often forced complex economic activities into simplistic, easily definable categories. In this category, every tenth employee was a home worker.

Interestingly, the 1951 business census explained that initially, the aim had been to distinguish home workers from self-employed "business owners". It was not possible, however, to realize this aim, because "the data did not allow for such a distinction to be made". ${ }^{2}$ The Finnish statistics seemed to be wholly reliant upon the assumption of a single employer employing individuals. The statistics lacked standard categories for contractors and intermediaries that would take into account the multilayered chains of employment. Hence, home workers moved to the margins of the business censuses, almost disappearing, which indicates that the importance of these workers was declining. In absolute terms, however, between $193^{1}$ and 1951, the reported number of home workers in Sweden increased from 14,00o to $32,500 .{ }^{33}$ Similarly, in Finland, whereas the 1953 business census listed 3,80o home workers, the number of reported home workers almost doubled in eleven years and in 1964, the census counted more than 6,ooo home workers. It is not entirely clear how these numbers were derived. ${ }^{34}$ This rise seems to have been due to changes in how the data were organized under the various categories. For instance, the 1964 census included electricians from remote areas in the countryside, who were employed by large power plant companies yet worked on their own and lived near the power stations, in the category of home workers. Many home industry

$30 \quad$ Elisabeth Prügl, "Biases in labor law", in Boris and Prügl (eds), Homeworkers in Global Perspective, pp. 210-11.

$31 \quad 1931$ års företagsräkning, p. 33.

321951 Census of Production, Distribution, and Services, p. 28.

33 Ibid., p. 181.

341964 General Economic Census, pp. 52-53. 
jobs were to be found listed under the category of consumer goods, such as the making of toys. The English-language summary in the census explained this oversight as follows: "Omission occurs in the case of very small enterprises, mainly such which have no enduring business premises". ${ }^{35}$ This suggests that such omissions pertained mainly to people who were employed elsewhere, yet occasionally earned income on their own account. The next sections will put these numbers into context.

\section{The Return of Home Industry in Interwar Sweden}

Historically, Swedish home industry was a rural phenomenon: it belonged to the putting-out system of textile weaving that took place on small, unproductive farms in the nineteenth century. ${ }^{36} \mathrm{~A}$ contractor would bring the materials to a farm, which the family worked on to earn extra income to supplement their farming work, especially during the long winter months. The contractor would then pick up and sell the finished products. ${ }^{37}$ The mechanization of the textile industry gradually replaced this type of home work in the later part of the nineteenth century. ${ }^{38}$

In the 1930s, persons employed in the Swedish manufacturing and services sectors outnumbered those working in the agricultural sector. Electrification and the manufacture of motor vehicles in the interwar period also led to a spread of small businesses. ${ }^{39}$ The surveys recorded a large number of microsized businesses: cafeterias, laundries, tailoring, shoemaking, and retailing. The majority of census returns at the time came from micro-sized companies and workshops run by self-employed proprietors and their family members. The Swedish business census of 1931 reported more than 90,000 manufacturing establishments.

Publications of the 1950s, looking back to the interwar period, reported innovations in materials, such as new synthetic fibres, logistics, and retailing

35 Ibid., p. 40.

36 Maths Isacson and Lars Magnusson, Proto-Industrialisation in Scandinavia: Craft Skills in the Industrial Revolution (Berg, 1987).

37 Gertrud Grenander-Nyberg, "Sömnadsindustrien: En översikt av dess uppkomst och utveckling i Sverige", in Torsten Althin (ed.), Daedalus: Tekniska museets årsbok (Stockholm, 1946), pp. $75^{-120}$, p. 8 o.

38 Ibid., p. 83; see also, Olsson, En västsvensk industrihistoria, pp. 52-53.

39 Lennart Schön, An Economic History of Modern Sweden, Routledge Explorations in Economic History 54 (Abingdon, 2012), p. 226; Andersson-Skog, "In the shadow of the Swedish welfare state", p. 457 . 
methods. Most notably, the entire concept of how to plan needlework completely changed towards taylorism-inspired management, standardization and measurement of different, specific tasks, unit pricing, and a more rational organization of production lines. One of the biggest changes in the interwar era was the introduction of the assembly line. These changes transformed the garment industry so completely that the economist Erik Dahmén wrote, in the early 1950s, that it was debatable whether it belonged to the same field of industry as earlier. ${ }^{40}$

Anecdotal evidence clashed with the images of speed and modern scientific management among scholars writing about the new working methods and assembly lines. Several major Swedish companies celebrated their success and published company histories as tribute volumes on the occasion of their anniversaries. These publications, written for their social peers, merely conveyed the image the company wanted to advertise. Interestingly, such volumes, published in the 1930s and 1940s, often mention home workers as an important resource in their formative years.

For instance, according to the company history of Erikson \& Larsson, two young men, O. Erikson and P. Larsson, moved to Borås from the countryside to start a small-scale business in ready-made work clothes. In the beginning, the entire production relied on home-based work. As the business grew, the firm hired representatives and soon thereafter, they opened an impressive factory in the town. ${ }^{41}$ Similarly, the Gothenburg-based Firma Gunnar Lind only had a warehouse when it started, with all production subcontracted to home workers. ${ }^{42}$ In Uddevalla, Schwartzman \& Nordström became, within a short period of time, the second largest industrial manufacturer in town. One consistent feature during its years of growth was the role of home workers. In 1920, the company had 260 employed workers and some 100 home workers. ${ }^{43}$

Most Swedish seamstresses ran ateliers with quite modest profits. How did they identify themselves in the 1931 census? When filling in the survey forms, some of the respondents had trouble identifying themselves as business proprietors. A sample consisting of seamstresses from Gothenburg reveals their confusion. Carolina Emilia Andersson, 64 years of age, reported that she was "sewing at home for private persons". Selma Matilda Gustafson used the exact

40 Dahmén, Svensk Industriell Företagarverksamhet, II; Kristensson, Studier i Svenska textila industriers struktur.

41 Aktiebolaget Erikson \& Larson, Borås 1892-1942: En minnesskrift (Göteborg, 1942).

42 Firma Gunnar Lind 1924-1949 (Göteborg, 1949), pp. 6-7.

43 Olsson, En västsvensk industrihistoria, p. 125; Robert Schwartzman, Aktiebolaget Schwartzman \& Nordström (Göteborg, 1943). 
same words, but then continued as follows: "I don't think this task refers to me; should I only report that I am sewing without any employees, while I am taking care of the household?" A third respondent, Alma Andersson, clarified her work status in the following manner: "[...] no other activity than home-based sewing, in an apartment of one room and a kitchen, no license to trade, no employees, thus I can hardly be identified as a business proprietor or anything like that". 44

The business census categorized such women as self-employed workers who managed their own accounts under the heading of seamstresses. It is not possible, however, to know the extent to which they had control of their own work. The term "private persons" most probably indicated customers who commissioned bespoke clothing from a seamstress, and may refer to the custom of visiting the homes of customers. It is likely, however, that occasionally the same seamstresses undertook piece-work for private persons. Herein lies the difficulty of distinguishing between home workers and self-employed business proprietors. The emergence of the "modern" Swedish garment industry also meant a boom in the demand for home-based sewing. ${ }^{45}$

\section{Postwar Economic Growth and the Home Industry in Sweden}

The 1950s were the golden years of the Swedish garment industry. Compared to the situation elsewhere in war-torn Europe, Sweden's infrastructure remained intact at the end of the Second World War. The garment industry produced goods for domestic use. This was a market with constantly increasing purchasing power, but also more leisure time among all classes. Demand rose for new types of clothing. ${ }^{46}$ For the Swedish garment industry, the most pressing problem in the postwar years was an acute shortage of workers. ${ }^{47}$

By the 195os, the total number of employees in the Swedish manufacturing sector (including owners and managers) reached the milestone figure of 1 million. The ready-to-wear garment industry alone employed nearly 44,000 people. ${ }^{48}$ Beneath the surface, though, the Swedish textile industry was

44 Swedish National Archives [hereafter SNA], Stockholm, Kommerskollegium, Företagsräkningen 1931, Ha: 372, translated from the original Swedish by the author.

45 Grenander-Nyberg, Sömnadsindustrien; see also Nilsson, "Taking work home”.

46 Gråbacke, Kläder, shopping och flärd, p. 102.

47 Johan Svanberg, "Migration at the multi-level intersection of industrial relations: The Schleswig-Holstein Campaign and the Swedish garment industry in the early 1950s", Scandinavian Economic History Review, 66 (2018), pp. 54-72, pp. 62-63. 1951 Census of Production, Distribution, and Services, p. 191. 
undergoing thorough structural changes. While the total number of employees across the textile and garment industries remained stable, the textile industry was reducing the number of employees. Most new jobs were to be found in the garment industry. 49

Table 2.1 illustrates three overlapping changes in the growing ready-to-wear sector, and how bespoke tailoring and seamstresses were affected. The table shows the disappearance of small tailors: between 1931 and 1951, 2,869 traditional tailors had disappeared. At the same time, the number of dressmakers remained practically the same. It is credible, but hard to prove, that some of them did commissioned work under contract for larger manufacturers.

Furthermore, where the 1931 business census showed approximately 13,500 jobs in the ready-to-wear manufacturing sector, as compared to 8,853 tailors and 600 seamstresses, by 1951, the number of employees in the ready-to-wear sector had increased to over 52,00o, when more than 8,00o home workers made ready-to-wear garments at home.

Through the postwar years, economic rationalization was a declared objective. The general wage level needed to improve, and this was possible due to the industrial renewal which kept productivity high. The balance and consensus for the rationalization measures were achieved through negotiated collective agreements between employers' organizations and workers' unions. ${ }^{50}$ Such policies favoured larger businesses. In the retail sector, small retailers experienced increased pressure from larger chains. Over the next two decades, an entire generation of small businesses disappeared. ${ }^{51}$ The logic underlying the existence of the garment industry was in conflict with the general economic policy of Sweden. In the garment industry, large firms were outliers rather than the norm and small companies continued to dominate. No matter how much the Swedish political system encouraged employers to negotiate with the unions, typically many ready-to-wear firms remained outside the employers' organizations. ${ }^{52}$

The $195^{1}$ business census returns offer a glimpse of the way in which production was organized. In 1951, the Swedish company Oscar Jacobson reported:

[We employ] home industrial workers /10/ plus commissioned work by independent firms and establishments. Our sales reported on page 3 also include products that we commission on piece-work from our

49 Gråbacke, Kläder, shopping och flärd, p. 344.

50 Schön, An Economic History of Modern Sweden, pp. 218-20.

$5^{1}$ Andersson-Skog, "In the shadow of the Swedish welfare state", p. 457.

$5^{2}$ Svanberg, "Migration at the multi-level intersection of industrial relations", pp. 62-63. 


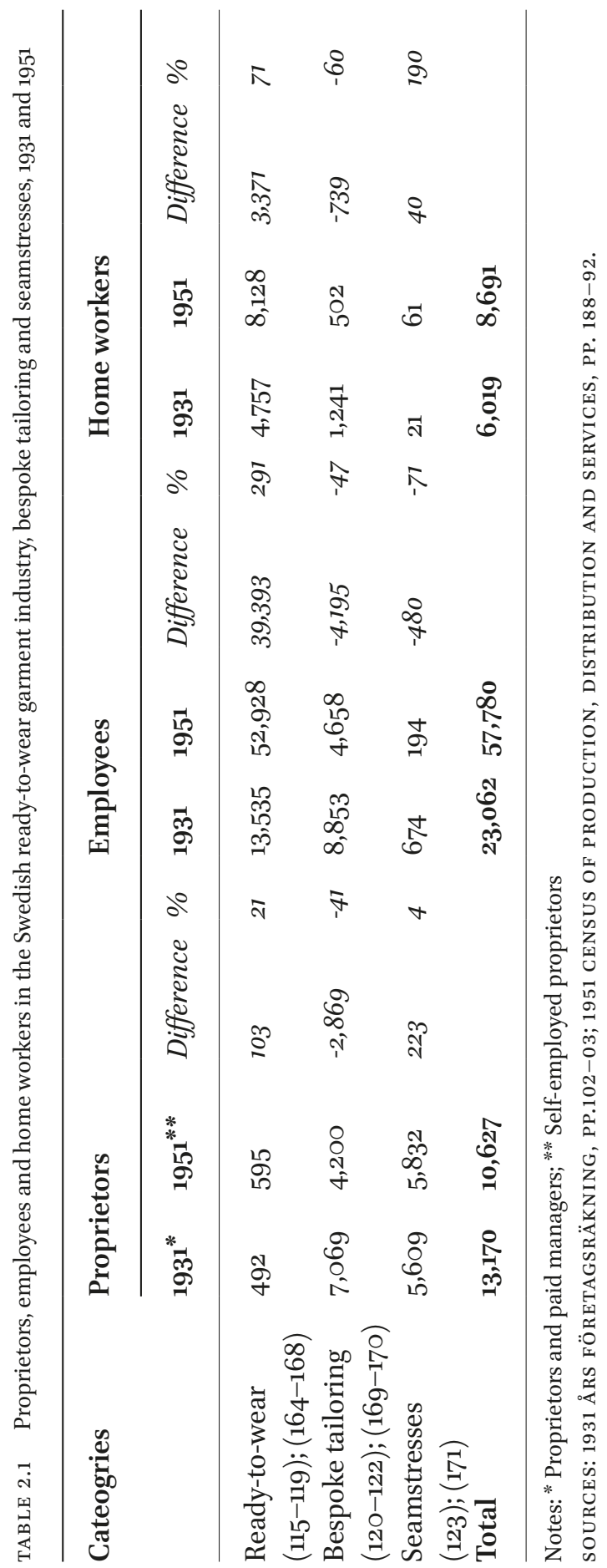


subcontractors. For instance, Karlskrona Aktiebolaget, from Karlskrona, has 95 workers producing [for us]. [...] whether and in what form our other subcontractors reported their work, we do not know, but we will take this issue up so as to avoid double accounting. ${ }^{53}$

Additionally, Oscar Jacobson reported that the company retained ten home workers on "commission to their own firms and residences". Thus we know that Karlskrona AB produced goods for Oscar Jacobson. Most likely, the mention of "other subcontractors" refers to small firms near the factory premises in the company's hometown of Borås.

Some firms specialized as intermediaries. For instance, Handelsfirman Källa, owned by Allan Källqvist, employed nineteen women home workers. Its field of business was "subcontracting needlework". ${ }^{4}$ The other companies running needlework workshops were less clear as to what their needlework included and who was doing the sewing. For instance, Syfabriken Textil, owned by Karin Gunnarson, seems to have been doing work for a larger company. The firm did "shirt sewing" and had six employees. Videx Konfektionsfabrik announced that it "runs a piecework business in the needlework business". Videx was owned and managed by Roland Widlund, and had five seamstresses and twenty home workers. ${ }^{55}$ Another company, Ab Erik Winter, employed four men and thirtyeight women. In addition, it had " 16 o seasonal home workers". ${ }^{56}$

Runéakonfektion, a small firm, declared that its operations involved homebased needlework: "in addition, I have in my own workplace done piecework for E G Eriksons Konfektionsfabrik in Sjömark [...] all work is done by me alone". ${ }^{57}$ What we do not know is whether this company reported its owner as a home worker or as a business partner. Table 2.2 illustrates the estimated shares of home workers in the textile and garment sectors in the years 1931 and 1951.

As shown in the table 2.2 below, from 1931 to 1951, the proportion of home workers among all employees in the garment manufacturing business hardly changed and did not show any drastic decrease. It seems safe to say, then, that throughout the golden years of the Swedish garment industry, the industry continued to rely on subcontracting and home work. The next section looks at the situation in Finland in the same period.

53 SNA, Stockholm, Kommerskollegium, Företagsräkningen 1951, Ha: 552.

54 Ibid.

55 Ibid.

56 Ibid.

57 Ibid. 
TABLE 2.2 Estimated numbers and proportions of home workers in the textile and garment sectors of Sweden, 1931 and 1951

\begin{tabular}{|c|c|c|c|c|}
\hline & 1931 & & 1951 & \\
\hline & $\left(105^{-127}\right)$ & $\%$ & $(141-178)$ & $\%$ \\
\hline $\begin{array}{l}\text { Employed } \\
\text { workers* }\end{array}$ & 65,138 & 85.0 & $1,20,842$ & $85 \cdot 3$ \\
\hline Home workers & 11,520 & 15.0 & 20,835 & $14 \cdot 7$ \\
\hline Total & 76,658 & 100.0 & $1,41,677$ & 100.0 \\
\hline
\end{tabular}

Note: Not including administrative and other office staff.

SOURCES: 1931 ÅRS FÖRETAGSRÄKNING, TABLE 1, PP. 42-43; 1951 ÅRS FÖRETAGSRÄKNING, TABLE A, PP. 30-31.

\section{Was Finland too Underdeveloped or too Modern for Home Industry?}

The take-off point of the Finnish ready-to-wear industry dates to the postSecond World War years. The wartime economy boosted the nascent clothing industry, as all firms involved in textile or garment production were obliged to deliver goods for military purposes. ${ }^{58}$ In the early 1950s, the Finnish clothing industry was still struggling under heavy postwar constraints. Consequently, domestic consumption and the demand for clothing were at considerably lower levels than in Sweden. Attitudes towards the garment industry were contradictory. In the immediate postwar years, an organization called the Central Organization of Cottage Industry Associations (Kotiteollisuusjärjestöjen Keskusliitto), promoted cottage industries as extra means of livelihood for unproductive rural farms. The government consciously established tens of thousands of small holdings for farmers who had lost their land to the Soviet Union. Cottage industry advocates persistently focused on the virtues of craftbased industry. According to their world view, craft work would bring much needed extra income to poor rural small-holders. ${ }^{59}$

58 Piippa Lappalainen and Mirja Almay, Kansakunnan Vaatettajat (Helsinki, 1996).

59 Eliza Kraatari, "Finnish Cottage Industry and Cultural Policy: A Historical View", Nordisk Kulturpolitisk Tidsskrift, 1 (2013), pp. 137-52. 
Home-based work in small farms leads one to ask if parallels can be drawn to the precarious conditions, high seasonality, and unaccounted work by unpaid family members that are typical of home industries. ${ }^{60}$ The self-accounts of the Finnish garment industry have, however, focused on mass-production techniques that enabled companies to produce large volumes of good-quality items at low prices. The clothes represented postwar recovery as well as modern Nordic values. Finnish design was about bright colours, futuristic forms, and comfortable, casual, mass-produced but well-designed, high-quality clothes for men, women, and children alike. The symbolic value of modern Finnish clothing was perhaps even greater than its economic value. When the First Lady of the United States and fashion icon Jackie Kennedy posed in a dress made by the Finnish company Marimekko in Sports Illustrated in 1960, the impact certainly was at a national level, well beyond the small clothing manufacturers of Helsinki.61 The implicit assumption was that the production line followed the norms of the Nordic policy models. The celebrated Marimekko found a niche in the U.S. market, while many more companies gained an advantage as a result of the 1961 European Free Trade Agreement. Finland, had a significantly lower wage level than Western Europe. ${ }^{62}$ For a brief period in the 1970 and early 1980 os Finland was a garment exporter, making clothes for companies like Britain's Marks \& Spencer, but also for the huge Soviet market. ${ }^{63}$

Notably, an outstanding collection of short histories of nearly all the major ready-to-wear producers in Finland, Kansakunnan vaatettajat, does not pay any attention to home workers or home-based work. ${ }^{64}$ The volume was compiled by Piippa Lappalainen and Mirja Almay, both designers with long careers in the Finnish clothing sector, as popular history looking back in time to the mid-199os, when Finnish producers were either shutting down operations or outsourcing production to cheaper countries. Hence, it is a collection of short

6o M.J. Boxer, "Protective Legislation and Home Industry: The Marginalization of Women Workers in Late Nineteenth-Early Twentieth-Century France", Journal of Social History, 20 (1986), pp. 45-65.

61 "196o Jackie Kennedy buys seven Marimekko dresses", www.company.marimekko.com, last accessed 5 May 2020.

62 Pirkko Haavisto, Suomen Vaatetusteollisuus: Kehitys vuosina 1965-1978 ja kehitysvaihtoehdot vuoteen 1990 (Helsinki, 1980).

63 Lappalainen and Almay, Kansakunnan Vaatettajat, pp. 123-25, 201-o3; for the relative ranking of Finland as an apparel exporter, see Kitty Dickerson, Textiles and Apparel in the Global Economy, third edn (Upper Saddle River, N.J., 1999), p. 194.

64 Lappalainen and Almay, Kansakunnan Vaatettajat. 
histories celebrating the heyday of Finnish clothing, and highlighting its modern and innovative design.

Finnish economists in the 196os noted that Finland, in comparison with the Scandinavian countries, had fewer industrial subcontracting jobs. ${ }^{65}$ As Fougstedt, Berndtson, and Lindståhl write: "The most important reason [for larger firm size] is no doubt that, in Finland, the process of industrialization has taken place later than in the other Nordic countries, so that, from the beginning, the industrial establishments given larger dimensions corresponding to the demands of the time". ${ }^{66}$ The economists observed that in many of the important branches of the economy, from mining to forestry and paper mills, economies of scale favoured mass production. The putting-out system was common in industrial sectors with relatively low mechanization and technical requirements. Since Finland industrialized later than the other Nordic countries, its industrial development "jumped over" the phase of many smallscale manufacturers typical of Swedish and Danish economic history. Finnish postwar taxation and credit policies further favoured big businesses. ${ }^{67}$

This analysis looked at the entire industrial manufacturing sector at an aggregate level. What may have been true for forestry and paper mills, though, seems less credible for garment manufacturing. At an empirical level, in the business censuses, the ready-to-wear producers of the mid-195os were small, family-owned companies. The line between artisanal work and industrial manufacturing was fluid. Many manufacturers were bespoke tailors or dressmakers rather than factory owners. ${ }^{68}$ Precise numbers are, however, hard to obtain. While the Swedish census reported the number of tailors and seamstresses, the Finnish census had no category for artisans. Therefore, in the Finnish case, it is not possible to estimate how many independent, self-employed proprietors might have worked in positions similar to that of home workers. Looking at the few tables that do mention home workers, such workers seem to have been rare and played no significant role in the development of the clothing industry-or in any other sector, for that matter. The numbers on their own suggest that the share of home industry in the Finnish garment industry was rather insignificant, and towards the mid-196os it diminished further.

Table 2.3 suggests that both the textile industry and ready-to wear industry used home workers. The table also indicates that the clothing industry provided

65 G. Fougstedt, H. Berndtson, and S. Lindståhl, Industrins storleksstruktur i Finland (Helsingfors, 1961).

66 Ibid., p. 57, English summary.

67 Ibid., p. 32.

68 National Archives of Finland, Helsinki, Liikeyrityslaskenta, LyL K18F: 38. 


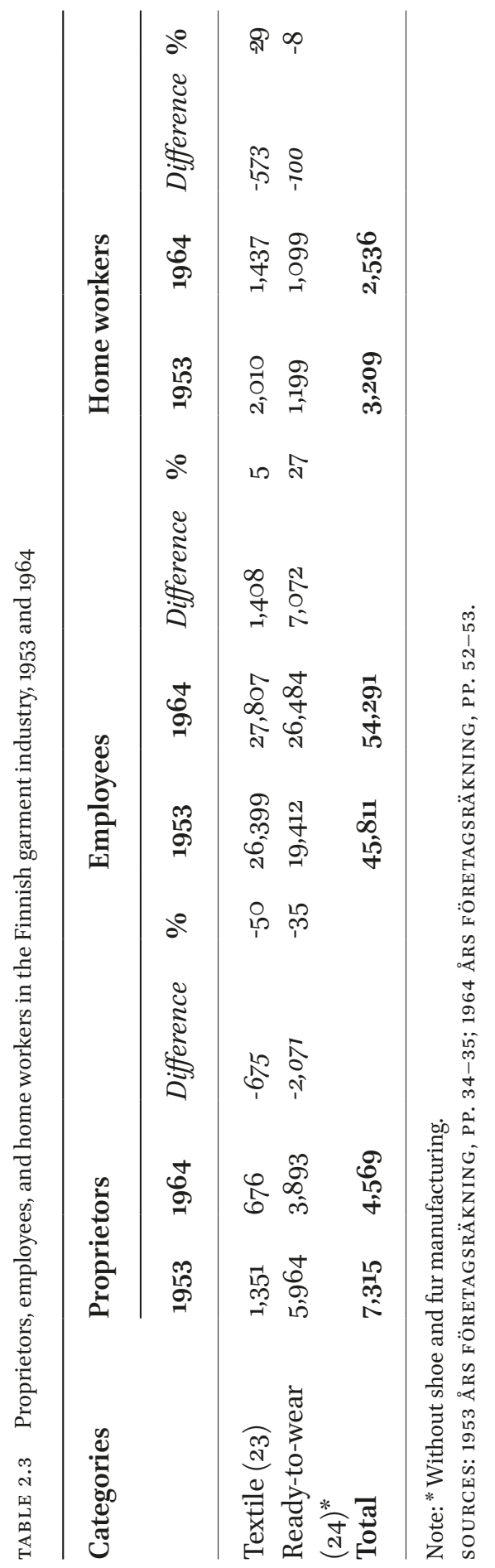


most of the new jobs. The number of home workers, however, decreased over time.

Table 2.3 shows that in less than a decade, from 1953 to 1964 , half of all the proprietors in the textile industry disappeared. In the garment manufacturing industry, more than 2,00o firms disappeared, while the number of jobs and employment in the manufacturing sector increased. The number of home workers in both sectors, textiles and garments, dropped. The fact that the census specifically mentions the industries removed from the list - the garment industry, construction work, and retailing - makes the matter more complicated. Both the garment industry and construction work were prone to subcontracting; and the line between employer and employee was often blurred in these sectors. This raises the question of whether "work for someone else" or, in English, "no enduring business premises" might still refer to home industry work.

The failure to mention home-based work in all published sources suggests that home workers indeed had little significance in Finland. The results may also correspond to underlying contemporary aspirations regarding the future of industrialization and economic growth. Rereading the business censuses suggests that at least in the initial stages, Finnish garment companies too relied on piece-work, contracts, and home workers. What, for example, did the iconic Finnish design house Marimekko report in the 1953 business census? The newly established firm described itself as an "apparel shop making women's wear of printed materials relying foremost on contracted work". Marimekko, in its early days, had a manager and three employees, two of whom were home workers. ${ }^{69}$

\section{6}

\section{Conclusion}

In many respects, extant literature on the Swedish and Finnish clothing industries countered the near-universal themes generally associated with the industry. The literature emphasized the "modern" aspect of Nordic clothing, namely, the introduction of assembly line-produced synthetic textiles and knowledgeintensive management in the larger companies. This part of the story fits well with the general narrative on the rise of the Nordic model, industrial rationalization, high productivity levels, and rising standards of living.

According to anecdotal evidence, home-based work formed a major part of the business strategy for start-ups in the Swedish apparel industry. Only as

69 National Archives of Finland, Helsinki, Liikeyrityslaskenta K18F:38/2445. 
the business grew did companies begin investing in modern facilities, or buy and convert existing small-scale textile factories into modern ready-to-wear businesses..$^{70}$ The enthusiasm for electrification and mechanization ignored this continuity and the renewal of home industry.

Censuses, like any form of knowledge production, are a sum of decisions and compromises. The Swedish and Finnish business censuses were clear in their definition of home workers, yet in practice it was often difficult to draw a line between home industry workers and self-employed business owners. Information disappears into the margins of the census tables due to an assumed decrease in social relevance.

The 1931 census in Sweden distinguished between different modes of production, including home production. In contrast, the 1951 census mostly ignored home-based work. The original census forms suggest that during the heyday of the locally oriented domestic garment industry, industrial subcontracting and home workers or a combination of these two types of labour were an integral part of garment production.

The literature on the Finnish garment industry recognizes neither homebased industrial work nor industrial subcontracting. The statistical accounts may have failed to provide information because it was not "out there" in the first place. At the outset, this seems to apply to the home worker question in Finland. Home workers barely appear in any of the sources. This makes for a story of an outlier category initially comprised of workers "too poor" for protoindustrialism, until the industry suddenly became defined by technologydriven and quality-based modern producers. The problem with the story line is its linear frame with the implicit assumption that any industrial sector must grow from small-scale firms to larger corporations. Despite all these shortcomings, the original forms of the business censuses are as close as one can get to information on short-lived, small companies in the ready-to-wear business. What kind of data were collected, and how they were measured, distinguished, and categorized, often affected the findings.

\section{Acknowledgements}

The research for this article was supported by the Emil Cedercreutz Foundation (Esko Rantanen grant) and by the Academy of Finland (grant 185640). 